\title{
The American Library in Paris Goes Technical
}

$\mathrm{A}^{\mathrm{N}}$

MONG the important postwar developments at the American Library in Paris is the establishment of a collection of modern American technical books. At a time when American books of all kinds are sought after, technical works are particularly in demand, because of the urgent need of France to modernize its factories and its farms and to make up for lost time and material damage resulting from the war. Accordingly, one of the greatest services that an American Library in Paris can perform is making available the latest information of American achievements in technical fields to French engineers, technicians, and farmers.

The American Library in Paris of prewar days possessed some technical books, but they were comparatively few, scattered as to subject, and largely out-of-date. When, therefore, in the spring of 1946 , it became possible to replenish the library's book stock for the first time since the beginning of the war, the trustees decided that special emphasis should be placed on engineering and allied subjects. With the advice of Milton E. Lord, director of the Boston Public Library, it was decided to base the purchases on McCombs' list of Books Published in the United States, 19391943; A Selection for Reference Libraries, on its continuation, the Harvard list of Books Published in the United States, I944, and on the United States Quarterly Book List for more recent publications. In addition, a special memorial collection of books on engineering was selected from a bibliography drawn up by the Engineering Societies Library and a collection of books on aviation was presented by Mrs. Richard E. Myers in memory of her son. To supplement the books, subscriptions to the principal engineering and aviation periodicals were acquired.

The remainder of this note will present an analysis of the reference use of these books during the first four months after they became available for use, i.e., Sept. I to Dec. 30, 1946. It must be remembered that this is a new service, not generally associated in the minds of the French public with the functions of the American $\mathrm{Li}$ brary in Paris, that little publicity has yet been given it, that the limited space at the library's disposal has not permitted the assignment of a separate room to these books, and, finally, that many of the books had not yet been fully cataloged. In spite of these limitations, the use already made of them indicates the need that exists.

\section{Statistics}

The following statistics have to do with the reference use of books in all the technical fields, including chemistry, physics, and agriculture, but not medicine or the pure sciences, other than chemistry and physics. During the month of September, when many people were still out of the city and when only a few of the new books were as yet available to the public, there were twenty-seven reference questions con- 
cerning technical subjects. In the three succeeding months, there were respectively forty-eight, forty-two, and forty-two. Also, much use was made of technical dictionaries and of such books as the Chemical Formulary. After a brief notice in the Paris paper, Le Monde, referring to the existence at the library of the National Research Council list of Scientific, Medical and Technical Books, there was an influx of readers wanting to consult it.

The largest number of questions in a particular field, forty-two in all, concerned manufacturing methods and industrial formulae. Translations of technical terms were second (3I); agriculture and animal husbandry, third (24). Next in frequency were chemistry (18), aviation (16), physics (13), and automobiles (II). There were also several questions touching each of the following subjects: architecture and building, metallurgy, electricity, military science and firearms, and technical education in the United States.

Users of the library included UNESCO, the scientific service of the French Army, a French airplane and automobile factory, a firm which sells machinery, professors, an agricultural engineer, a representatiye of the Hungarian government, a decorator of airplanes, a publisher, a cosmetics manufacturer, a maker of soft drinks, a member of the R.A.F., an architect, and translators of technical articles.

\section{Examples}

A sampling of questions, taken more or less at random, includes: the translation of "soda lime," "annealed," "calcine," and of various aviation terms; information on hosiery and textile machines; airplane construction in the United States; books on tractors and other agricultural machines; information about plywood, refrigeration, and firearms; formulae for making cosmetics; horse-breeding; distillation; the A.S.T.M. standards for electric insulation; the density of the royal coconut palm; new processes in the manufacture of glass; the enameling of metals; chemical analysis of foods; rocket-projectiles; painting and woodworking; the effect of the atomic bomb on concrete; electric motors; new methods of utilizing wood; school and university architecture in the United States; the cultivation and exploitation of sugar cane, vanilla, lemon grass, etc. ; dairy farming; and pumps and wells.

It is obvious that what has been done is only a beginning. The library must continue to build up its collections and to make them known to the French public, but the start made clearly indicates the need for American technical books in Paris. 